\title{
APPLICATION OF THE DECISION SUPPORT MODEL TO CZECH EXPORTS
}

\author{
Matěj Urban, Michal Mejstř́ík, Jana Gutierrez Chvalkovská*
}

\section{Introduction}

This paper presents modification, calibration and application of the Export Decision Support Model (EDSM) based on Cuyvers et al. (1995), Cuyvers (1996), Cuyvers (2004), Cuyvers et al. (2009) and Pearson et al. (2010) as a tool for identification of export opportunities. The cited papers identify suitable export opportunities for Belgium, Thailand and the Republic of South Africa. Our EDSM is designed specifically for the Czech Republic and, compared to earlier studies, it uses different critical values and adds important selection criteria with respect to the specifics of the Czech economy, which is small and highly export-oriented with a strong focus on manufacturing. Based on data from the Czech Statistical Office, the gross export accounted for $79.6 \%$ and the net export for $8.1 \%$ of the Czech GDP in 2012 with a strong focus on EU countries (80.8\% of Czech exports was to EU countries). An important improvement to previous studies is that our approach emphasises more the supply side of export opportunities, and also takes into account the import content of exports and enables flexibility for various industries with respect to country risk, GDP growth and the Ease of Doing Business (World Bank Index). The second stage of our model combines the results of the general EDSM with additional factors to allow an individual sector or regional approach.

The main objective of this study is to demonstrate the modification of the EDSM for the particular features of the Czech Republic, and show how it was applied to an assessment of the Czech Export Strategy. The paper is structured as follows: In the second section, we build the EDSM for the Czech Republic and explain the process of prioritising export markets based on the Index of Export Opportunities. The third section introduces the data used in the model. The fourth section presents the results of the model and compares them to the priority markets from the Czech Export Strategy. Finally, the last section concludes the paper.

\footnotetext{
* Matěj Urban, EEIP, a.s., Praha; Michal Mejstř́ik, Charles University in Prague; Jana Chvalkovská, Charles University in Prague (matej.urban@eeip.cz).

This paper was created as a part of the project "The system of evaluation of the competitiveness of exports of goods and services", which was supported by the grant TD010137 from the Technology Agency of the Czech Republic.
} 


\section{The EDSM}

The main motivation of this paper is to apply the EDSM to identify the Czech Republic's export opportunities, which might help to better target the Czech Republic's export promotion policy. The model is applied to assess the priority countries selected by the Czech Export Strategy and, besides, it enables us to specify priority markets for various industries. This makes the model a flexible instrument that can be used for export recommendations on the national and industry levels.

The selection process of suitable export opportunities consists of sequential elimination of less interesting markets, which are gradually filtered based on specific selection criteria. The selection of the elimination criteria is inspired by Pearson et al. (2010); however, our approach brings three major improvements and calibrates the model specifically for the Czech Republic.

Firstly, we do not use the indicator of country risk in the first step of the elimination. That enables us to preserve the possibility of an individual approach towards various industries that differ in their exposure to political and commercial risks. The EDSM also uses a similar approach in the case of expected GDP growth, enabling a selection of its desirable weight for the final ranking of desired markets.

Besides, we have incorporated additional filters into our modified EDSM, using the Lafay index (Lafay, 1992) and the index of revealed comparative advantage (Balassa, 1965), which reflect not only the demand side of export opportunities, but also the supply side, thus reflecting the ability of Czech exports to succeed on foreign markets.

Another important addition to Pearson et al. (2010) is that we took into account the global value chains, which is especially important for a small and open economy such as the Czech Republic. Only a part of the exported volume is formed by domestic value added, thus the absolute volumes of trade are often misleading indicators. Hence, in order to partially reflect where the real value added of exports was created, the model adjusts critical values for market size based on the import content of exports.

The thresholds for sequential filtration of export opportunities were selected on the basis of a calibration process, during which we tested the model on export opportunities for specific markets and product groups along with specific geographical locations.

The selection of the calibration method was influenced by the following aspects:

- the EDSM is a multi-criteria model with a number of parameters;

- the EDSM is required to find favourable export opportunities for the whole economy as well as for individual subcategories with different specificities;

- ranking of parameter significance in determining good export opportunities cannot be set in an unambiguous way;

- some of the variables show a high degree of multicollinearity, which makes traditional regression methods difficult to use;

- emphasis was on the model applicability in common practice. 
Therefore, one of the assumptions of the calibration process is that successful export in the past is an opportunity in the future ${ }^{1}$. We selected a reference group of exports consisting of export opportunities based on objective criteria ${ }^{2}$ from the past and other export opportunities identified as propitious by Czech embassies and trade promotion organisations such as CzechTrade. The reference group consisted of 350 export opportunities. For finding optimal sensitivity to various criteria, we tried to build similar reference groups of export opportunities for various subcategories including both country-specific markets and product-specific markets. The model was also tested on a few specific Czech exporters (real-life cases). Finally, the calibration process found the threshold values by minimising the type I error for all the cases while keeping the required number of opportunities and some basic setups of parameters from Pearson et al. (2010).

The structure of the sequential filtration is a result of attempts to maintain a balance between the supply and demand sides of export, trends in import, trade barriers, risks and global value chains. We use five filters to identify the final sample of export opportunities. The purpose and structure of the filters is explained in the text below.

First, we selected export opportunities based on the size of the importing market and its short-term and medium-term growth. As indicated by Havrlant et al. (2011), among the most important factors driving the Czech export are foreign demand (especially demand from EU countries), cost factors and the exchange rate. Cost factors and the exchange rate play a substantial role in the dynamics of the Czech export because they make up the price competitiveness of the country. The price competitiveness reflects the comparative advantage of a country, which usually (omitting the trade barriers) results in the revealed comparative advantage (RCA). Thus, the specialisation on respective products of the Czech Republic was taken into account as indicated by the RCA modified by the import content of exports in order to encompass where the value added was created. The critical value for export growth was calculated as follows:

$$
G_{j}=\left\{\begin{array}{c}
g_{w, j} s_{j} \text { if } g_{w, j}>0 \\
g_{w, j} / s_{j} \text { if } g_{w, j} \leq 0
\end{array}\right\}
$$

where

gwj is the growth of world export of the product $\mathrm{j}$ in the last year and last 3 years respectively;

$S_{j}=0.8+\frac{1}{\left(R C A_{j}+0.85\right) e^{\left(R C A_{j}-0.01\right)}} \quad$ denotes a scaling factor ${ }^{3}$.

1 The model searches for both new export opportunities and opportunities that are based on past successful exports.

2 The size of gross export, export of value added, export growth, relative product and country specialization.

3 It is the same scaling factor as at Pearson et al. (2010) except the fact that RCA is modified by the import content of exports. 
The scaling factor consists of the revealed comparative advantage (RCA) and the import content of exports.

$$
R C A_{j}=\left(\frac{X_{c z, j}\left(1-F V A_{c z, j}\right)}{X_{w, j}}\right) /\left(\frac{X_{c z}\left(1-F V A_{c z}\right)}{X_{w}}\right),
$$

where

$\mathrm{X}_{\mathrm{cz}, \mathrm{j}} \quad$ is the Czech export of the product $\mathrm{j}$

$\mathrm{X}_{\mathrm{cz}} \quad$ is the total Czech export

$\mathrm{X}_{\mathrm{w}, \mathrm{j}} \quad$ is the world export of the product $\mathrm{j}$

$\mathrm{X}_{\mathrm{W}} \quad$ is the total world export

$\mathrm{FVA}_{\mathrm{cz}, \mathrm{j}}$ is the average import content of exports in the industry of the product $\mathrm{j}$ (as a share in gross export)

$\mathrm{FVA}_{\mathrm{cz}}$ is the average import content of the Czech export (as a share in gross export)

We applied a similar approach in the case of the relative size of the importing market. The critical value was calculated as follows:

$$
S_{j}=\left\{\begin{array}{c}
0.02 M_{w, j} \text { if } R C A_{j}>1 \\
{\left[\frac{3-R C A_{j}}{100}\right] \times M_{w, j} \text { if } R C A j \leq 1}
\end{array}\right\},
$$

where

$\mathrm{M}_{\mathrm{w}, \mathrm{j}} \quad$ is the world import of the product $\mathrm{j}$.

Then, we sorted the potential export opportunities into categories based on the condition whether the import growth of the product $j$ to the country $i$ and the import volume of the product $j$ to the country $i$ was larger than or equal to the critical value ( 0 if not fulfilled, 1 if fulfilled). The first step of elimination removed export opportunities where Filter 1 equals 0 (see Table 1 for the classification). The following table summarises the classification into 8 categories: 


\section{Table 1}

\section{Classification of export opportunities based on importing markets}

\begin{tabular}{ccccc}
\hline Filter 1 & Category & $\begin{array}{c}\text { Short-term } \\
\text { growth }\end{array}$ & $\begin{array}{c}\text { Mid-term } \\
\text { growth }\end{array}$ & $\begin{array}{c}\text { Market } \\
\text { size }\end{array}$ \\
\hline 0 & 0 & 0 & 0 & 0 \\
0 & 1 & 1 & 0 & 0 \\
0 & 2 & 0 & 1 & 0 \\
1 & 3 & 0 & 0 & 1 \\
2 & 4 & 1 & 1 & 0 \\
2 & 5 & 1 & 0 & 1 \\
2 & 6 & 0 & 1 & 1 \\
3 & 7 & 1 & 1 & 1 \\
\hline
\end{tabular}

Source: authors.

During the second step of the elimination process, we removed opportunities with large trade barriers and difficult market penetration. Filter 2(a) uses the Herfindahl-Hirschmann Index (HHI) to measure market concentration (Hirschmann, 1964). We assumed that it was usually easier to penetrate less concentrated markets and thus we eliminated export opportunities where the HHI was higher than the critical values. The critical values for Filter 2(a) are the result of the calibration process and depend on Filter 1 as follows:

$$
\begin{aligned}
& 0.085 \text { if Filter } 1=1, \\
& 0.529 \text { if Filter } 1=2, \\
& 0.973 \text { if Filter } 1=3 .
\end{aligned}
$$

Filter 2(b) uses the assumption of Cuyvers (2004) that if countries with similar export structures and geographical locations are able to penetrate a specific market, then also the country of interest can penetrate the market. We used Germany to measure the revealed absence of trade for the Czech Republic, because Germany is a neighbouring country and it has a similar structure of export, measured by the Export Similarity Index (Finger et al., 1979). Germany has the highest value (0.507) of the Export Similarity Index for the Czech Republic. Thus, Germany has a supply structure of products for export similar to that of the Czech Republic, but is more successful in penetrating foreign markets. Filter 2(b) is determined as follows:

$$
\text { Filter } 2(b)=\left\{\begin{array}{l}
1 \text { if } m_{i, j}>0.95 \\
0 \text { if } m_{i, j} \leq 0.95
\end{array}\right\},
$$


where:

$$
m_{i, j}=\frac{\frac{X_{G, i, j}}{X_{G, j}}}{\frac{X_{w, i, j}}{X_{w, j}}}
$$

$\mathrm{X}_{\mathrm{G}, \mathrm{i}, \mathrm{j}} \quad$ is Germany's export of the product $\mathrm{j}$ to the country $\mathrm{i}$,

$\mathrm{X}_{\mathrm{G}, \mathrm{j}} \quad$ is Germany's export of the product $\mathrm{j}$,

$\mathrm{X}_{\mathrm{W}, \mathrm{i}, \mathrm{j}} \quad$ is the world export of the product $\mathrm{j}$ to the country $\mathrm{i}$,

$\mathrm{X}_{\mathrm{W}, \mathrm{j}} \quad$ is the total world export of the product $\mathrm{j}$.

Another barrier for trade is the transportation costs, which usually increase with the transport distance. Filter 2(c) works with the distance $\left(\mathrm{d}_{\mathrm{i}}\right)$ of the country's capital to Prague. The critical values for Filter 2(c) are as follows:

$$
\text { Filter } 2(c)=\left\{\begin{array}{c}
2 \text { if } d_{i} \leq 2,500 \mathrm{~km} \\
1 \text { if } 2,500 \mathrm{~km}<d_{i} \leq 8,500 \mathrm{~km} \\
0 \text { if } d_{i}>8,500 \mathrm{~km}
\end{array}\right\}
$$

Filter 2 then combines Filter 2(b) and Filter 2(c), thus eliminating the export opportunities where both parts were equal to zero.

Both the supply side and the demand side of the export opportunities are incorporated into the model by means of Filter 3. Filter 3 compares the value of the Lafay index (valuing the comparative advantage of the Czech Republic) with that of a potential trade partner and chooses the opportunities where the Czech Republic has a relative comparative advantage. The export opportunities are divided into 4 categories and then eliminated if Filter 3 equals zero.

$$
\text { Filter } 3=\left\{\begin{array}{c}
0 \text { if } L F I_{c z e, j}-L F I_{i, j}<0 \\
1 \text { if } 0 \leq L F I_{c z e, j}-L F I_{i, j}<0.025 \\
2 \text { if } 0.025 \leq L F I_{c z e, j}-L F I_{i, j}<0.2 \\
3 \text { if } L F I_{c z e, j}-L F I_{i, j} \geq 0.2
\end{array}\right\},
$$

where

$$
L F I_{i j t}=\left[\frac{X_{i j t}-M_{i j t}}{X_{i j t}+M_{i j t}}-\frac{\sum_{j=1}^{k}\left(X_{i j t}-M_{i j t}\right)}{\sum_{j=1}^{k}\left(X_{i j t}+M_{i j t}\right)}\right] \times \frac{\left(X_{i j t}+M_{i j t}\right)}{\sum_{j=1}^{k}\left(X_{i j t}+M_{i j t}\right)} \quad \text { is a Lafay index, }
$$

i stands for the country,

j stands for the product, 
$\mathrm{t} \quad$ stands for the year,

M stands for import,

X stands for export.

Filter 4 helps to sort the export opportunities based on market importance. We used Filter 4 for further elimination only in combination with other filters (see Equation (9) for the final purge of export opportunities).

To determine whether the Czech Republic has a relatively large or small market share for a specific product group and country, we compared the degree of market importance of the Czech Republic with the top 6 exporting countries in the product group $\mathrm{j}$ to the country $\mathrm{i}$. The EDSM calibration process brought the following critical values for Filter 4:

$$
\text { Filter } 4=\left\{\begin{array}{c}
0 \text { if } M I_{\text {top } 6, i, j}-M I_{c z e, i, j} \geq 2.35 \\
1 \text { if } 1.6 \leq M I_{\text {top } 6, i, j}-M I_{c z e, i, j}<2.35 \\
2 \text { if } 0.9 \leq M I_{\text {top } 6, i, j}-M I_{c z e, i, j}<1.6 \\
3 \text { if } M I_{\text {top } 6, i, j}-M I_{c z e, i, j}<0.9
\end{array}\right\},
$$

where

$M I_{n, i, j}=\frac{\frac{X_{n, i, j}}{X_{w, i, j}}}{\frac{X_{n, j}}{X_{w, j}}}$,

$X_{n, i, j} \quad$ denotes the export of the product $\mathrm{j}$ by the country $\mathrm{n}$ to the country $\mathrm{i}$,

$X_{W, i, j} \quad$ denotes the total world export of the product $\mathrm{j}$ to the country $\mathrm{i}$,

$X_{n, j} \quad$ denotes the export of the product $\mathrm{j}$ by the country $\mathrm{n}$,

$X_{W, j} \quad$ denotes the total world export of the product $\mathrm{j}$,

$M I_{\text {top } 6, i, j}$ denotes the market importance of the top 6 exporters in the product group $\mathrm{j}$ to the country i,

$M I_{c z e, i, j} \quad$ denotes the market importance of exporting the product group $\mathrm{j}$ to the country $\mathrm{i}$ for the Czech Republic.

Until now, we have used filters for selecting appropriate markets for every product, taking into account the supply side of the export opportunities. However, we have not prioritised among the products with regard to the potential to increase the competitiveness of the Czech economy. We therefore wanted to incorporate the export sophistication in order to favour those opportunities that are worth being supported in export promoting activities. Filter 5 thus uses the PRODY index (Anand et al., 2011) to classify export opportunities according to the perspective of the product for the Czech 
Republic. We use the Filter 5 for further elimination only in combination with other filters. As a result of the calibration, the critical values were selected as follows:

$$
\text { Filter } 5=\left\{\begin{array}{c}
0 \text { if } P R O D Y_{j}<10,000 \\
1 \text { if } 10,000 \leq P R O D Y_{j}<18,000 \\
2 \text { if } 18,000 \leq P R O D Y_{j}<26,000 \\
3 \text { if } \operatorname{PRODY}_{j} \geq 26,000
\end{array}\right\} \text {, }
$$

where

$$
\operatorname{PRODY}_{j}=\sum_{i} \frac{\frac{X_{i, j}}{X_{i}}}{\sum_{i} \frac{X_{i, j}}{X_{i}}} Y_{i},
$$

$Y_{i} \quad$ denotes the GDP per capita of the country $\mathrm{i}$ in international dollars.

In the last step of the elimination, we combined Filters 1, 3, 4 and 5 in order to make the final purge of less interesting export opportunities. The specific value of the threshold is a result of a calibration process and model testing. We eliminated export opportunities, where:

$$
\text { Filter } 1+\text { Filter } 3+\text { Filter } 4+\text { Filter } 5<8
$$

After the elimination process, we needed to incorporate additional factors, allowing an individual approach for different industries. The EDSM does not reflect the country risk and expected growth when selecting desired export opportunities. We therefore created the Index of Export Opportunities (IEP) to enable combinations of the results of the general EDSM with additional criteria.

The IEP is structured as the weighted average of normalised export opportunities determined by the EDSM (IEDSM), normalised rank of the country in the Ease of Doing Business (IDB), normalised Economic Complexity Index (IEC) and normalised expected economic growth until 2018 (IEG). The IEP takes values from 0 to 1 . The country with the highest number of export opportunities reaches the value one, while the IEP of countries with no opportunities equals zero.

$$
I E P_{i}=w_{E D S M} I E D S M_{i}+w_{D B} I D B_{i}+w_{E G} I E G_{i}+w_{E C} I E C_{i}
$$

where

$$
\operatorname{IEDSM}_{i}=\frac{O_{i}-\min _{1 \leq n \leq N}\left\{O_{n}\right\}}{\max _{1 \leq n \leq N}\left\{O_{n}\right\}-\min _{1 \leq n \leq N}\left\{O_{n}\right\}},
$$




$$
\begin{aligned}
& I D B_{i}=1-\frac{D B_{i}}{N}, \\
& I D B_{i}=1-\frac{D B_{i}}{N}, \\
& I E G_{i}=\frac{E G_{i}-\min _{1 \leq n \leq N}\left\{E G_{n}\right\}}{\max _{1 \leq n \leq N}\left\{E G_{n}\right\}-\min _{1 \leq n \leq N}\left\{E G_{n}\right\}}, \\
& I E C_{i}=\frac{E C_{i}-\min _{1 \leq n \leq N}\left\{E C_{n}\right\}}{\max _{1 \leq n \leq N}\left\{E C_{n}\right\}-\min _{1 \leq n \leq N}\left\{E C_{n}\right\}}, \\
& w_{E D S M}+w_{D B}+w_{E G}+w_{E C}=1,
\end{aligned}
$$

$\mathrm{N}$ denotes the number of countries with at least one export opportunity,

$\mathrm{O}_{\mathrm{i}} \quad$ denotes the number of export opportunities to the country $\mathrm{i}$,

$\mathrm{DB}_{\mathrm{i}} \quad$ denotes the rank of the country $\mathrm{i}$ in Ease of Doing Business,

$E_{i} \quad$ denotes the expected cumulative GDP growth of the country $i$ until 2018,

$\mathrm{EC}_{\mathrm{i}} \quad$ denotes the value of the index of Economic Complexity of the country $i$.

The following figure visualises the procedure of export opportunity selection and combination of the EDSM with other criteria.

\section{Figure 1}

Procedure of market ranking

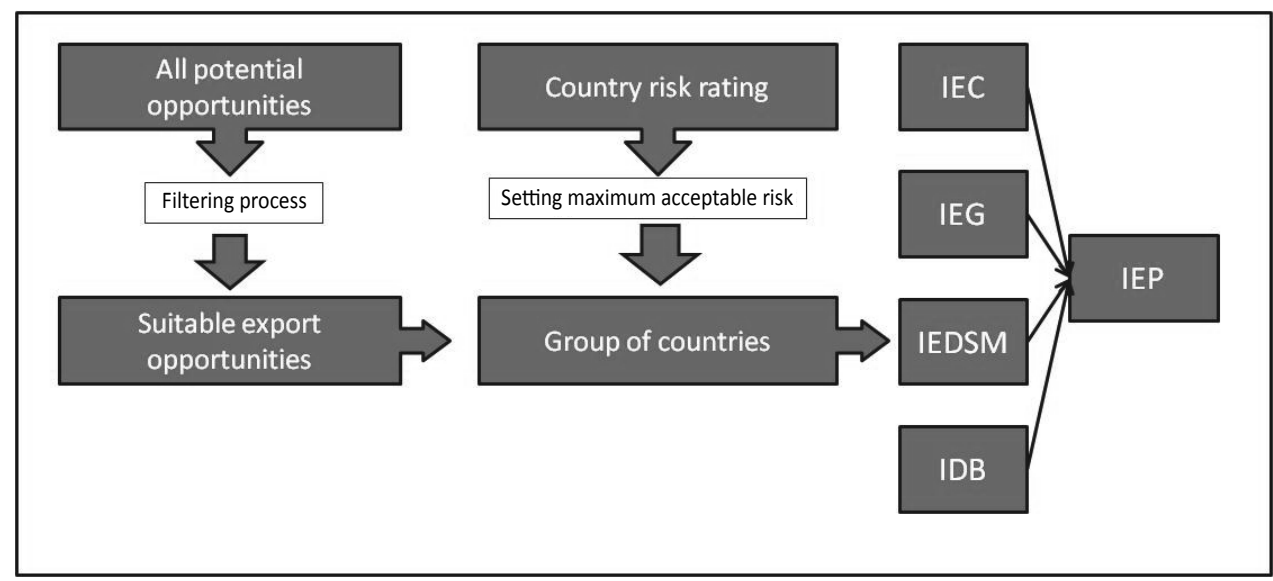

Source: authors. 


\section{Data}

The model uses annual values of exports and imports among countries classified according to the Harmonised System of tariff nomenclature (to the 6-digit level, HS6) for 2006-2010. We use the Comtrade database as a data source, which provides volumes of imports and exports in USD. Furthermore, the model uses GDP and GDP per capita, including their forecast by the IMF. The import content of exports was estimated based on approximated data of OECD and WTO that assign each sector with an import content of exports (on the basis of the ISIC rev. 3 classification).

We developed a model for selecting export opportunities in a wider version, where the users can combine the main results of the EDSM with other factors such as: country risk - OECD (2013), the Ease of Doing Business indicator - World Bank (2013) and the Economic Complexity Index - Observatory of Economic Complexity (2008).

The sample covers 176 countries and 5,920 products according to HS6 classification. All the combinations of products and countries are considered as potential export opportunities (1,041,920 combinations in total). After an elimination process, only 20,041 export opportunities are considered desirable.

The back-testing of the critical values in the calibration process was made on the basis of a comparison between the results and the real demand for Czech products based on information from Czech embassies and trade promotion organisations (for example, the CzechTrade map of sector opportunities).

\section{Results}

After the completion of the filtering process as described in Section 2, we divided the product groups into categories. The EDSM identified most of the opportunities for the Czech Republic in machinery and electrical equipment $(6,544)$, followed by metal products $(2,479)$, mixed, other $(1,799)$ and plastics/rubber $(1,345)$, as depicted in the following tables showing the frequency of opportunities by product groups.

\section{Table 2}

Export opportunities for the Czech Republic by categories (containing 2 or more HS2 categories)

\begin{tabular}{lcc}
\hline \multicolumn{1}{c}{ category } & $\begin{array}{c}\text { covered HS2 } \\
\text { groups }\end{array}$ & opportunities \\
\hline machinery and & $84-85$ & 6,544 \\
electrical equipment & & \\
metal products & $72-83$ & 2,479 \\
mixed, other & $90-97$ & 2,392 \\
plastics/rubber & $39-40$ & 1,799 \\
stone/glass & $68-71$ & 1,283 \\
textile & $50-63$ & 1,173 \\
total & & $\mathbf{2 0 , 0 4 1}$ \\
\hline
\end{tabular}

unit: HS6 - country combination

Source: authors. 


\section{Table 3}

\section{Export opportunities for the Czech Republic by HS2 product groups}

\begin{tabular}{clc}
\hline HS2 category & \multicolumn{1}{c}{ description } & opportunities \\
\hline 84 & Nuclear reactors, boilers, machinery, etc & 4,222 \\
85 & Electrical, electronic equipment & 2,322 \\
90 & Optical, photo, technical, medical, etc apparatus & 1,072 \\
73 & Articles of iron or steel & 918 \\
70 & Glass and glassware & 727 \\
87 & Vehicles other than railway, tramway & 720 \\
40 & Rubber and articles thereof & 677 \\
39 & Plastics and articles thereof & 668 \\
82 & Tools, implements, cutlery, etc of base metal & 553 \\
29 & Organic chemicals & 546 \\
\hline
\end{tabular}

unit: HS6 - country combination

Source: authors.

The following map displays the priority markets for machinery/electrical equipment (in terms of the IEP). The model finds the highest number of export opportunities for machinery/electrical equipment in Russia, followed by India, Egypt, China and Germany.

\section{Figure 2}

Map of export opportunities of machinery/electrical products (higher IEP means higher frequency of export opportunities)

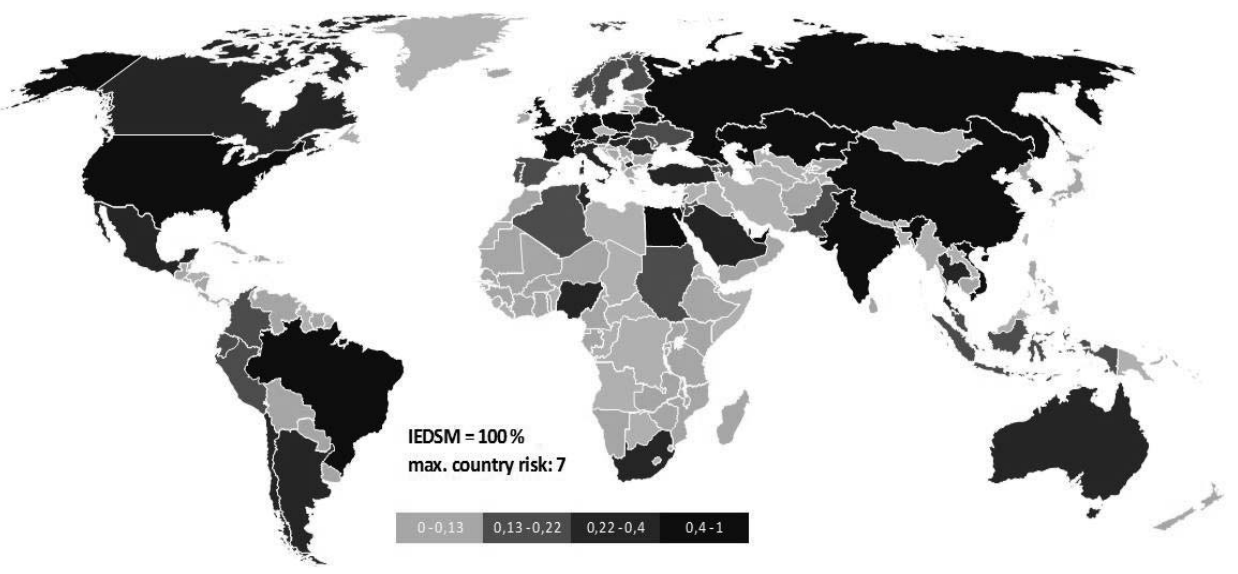

Source: authors 
The following table simulates ${ }^{4}$ how the ranking of suitable markets for machinery and electrical equipment changes with different weights for the IEDSM, IEG, IEC, IDB and maximum country risk (country risk by OECD).

\section{Table 4}

\section{Market ranking for machinery/electrical products}

\begin{tabular}{lcccc}
\hline & simulation 1 & simulation 2 & simulation 3 & simulation 4 \\
\hline \multirow{5}{*}{ weights } & IEDSM: $100 \%$ & IEDSM: $70 \%$ & IEDSM: $70 \%$ & IEDSM: $40 \%$ \\
& IEG: $0 \%$ & IEG: $0 \%$ & IEG: $30 \%$ & IEG: $20 \%$ \\
& IEC: $0 \%$ & IEC: $0 \%$ & IEC: $0 \%$ & IEC: $20 \%$ \\
& IDB: $0 \%$ & IDB: $30 \%$ & IDB: $0 \%$ & IDB: $20 \%$ \\
\hline Russia & max. country risk: 7 & max. country risk: 4 & max. country risk: 4 & max. country risk: 1 \\
India & 1 & 1 & 1 & $\mathrm{X}$ \\
Egypt & 2 & 9 & 3 & $\mathrm{X}$ \\
Germany & 3 & $\mathrm{X}$ & $\mathrm{X}$ & $\mathrm{X}$ \\
China & 4 & 2 & 5 & 1 \\
Belarus & 5 & 7 & 2 & $\mathrm{X}$ \\
Brazil & 6 & $\mathrm{X}$ & $\mathrm{X}$ & $\mathrm{X}$ \\
Kazakhstan & 7 & 16 & 4 & $\mathrm{X}$ \\
France & 8 & $\mathrm{X}$ & $\mathrm{X}$ & 5 \\
USA & 9 & 4 & 10 & 2 \\
Slovakia & 10 & 3 & 6 & 6 \\
UAE & 11 & 8 & 8 & $\mathrm{X}$ \\
Poland & 12 & 5 & 7 & 9 \\
GB & 13 & 11 & 9 & 4 \\
Korea & 15 & 6 & 15 & 3 \\
Switzerland & 18 & 12 & 13 & 8 \\
\hline
\end{tabular}

Source: authors.

The simulation shows that putting more weight on the IDB factor favours countries with well-developed institutions while putting more weight on the IEG improves the score of fast-growing developing countries. Besides, increasing the weight of the IEC leads to a better score for countries with high knowledge intensity and export sophistication.

The results of the model (for the entire portfolio of product categories) were used for verification of the correct setting of the priority and interest countries in the Czech Export Strategy 2012-2020, which identifies priority and interest countries outside the EU (see the Appendix). The following map illustrates the preferred markets (expressed by the IEP) as a result of the general EDSM applied to the entire portfolio of products.

4 Deterministic simulation based on changing parameters. 


\section{Figure 3}

\section{Map of export opportunities of the Czech Republic given by the EDSM}

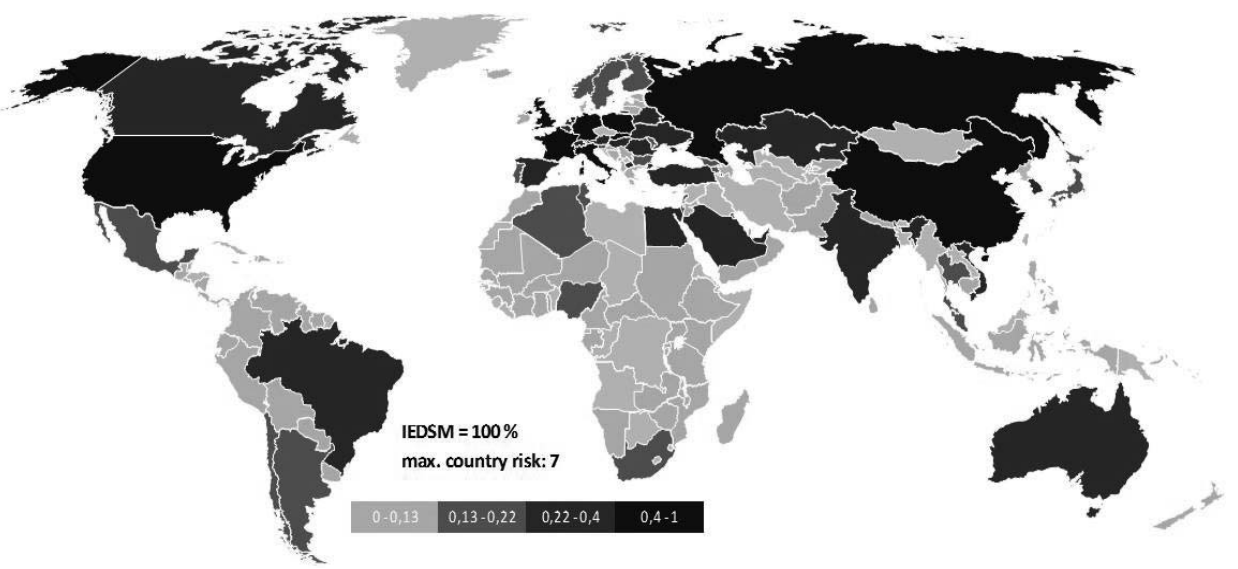

Source: authors.

It can be seen that the priority countries as described in the Strategy correspond to the countries preferred by the EDSM in the majority of cases.

The EDSM assigns the most export opportunities to Germany $(1,016)$, followed by Russia (866), Poland (650), Slovakia (629) and France (612). However, many of these opportunities, especially in Europe ${ }^{5}$, have already been discovered by Czech exporters. Thus, we can find many unused opportunities outside the European continent. The Czech exports are highly dependent on imports from the EU, therefore the Czech Export Strategy 2012-2020 defines the key priority of keeping the position on the EU market, but also penetrating markets outside the EU, especially those markets defined as the priority and interest markets. From the perspective of the EDSM, the following countries have a very interesting potential for Czech exports: Kazakhstan, Brazil, the United Arab Emirates, China, India, Turkey, Belarus, Russia, USA, Georgia, Egypt, Saudi Arabia, Australia, Canada, and Vietnam.

The robustness of the model was tested by varying cut-off values and comparing the results for the entire portfolio of export opportunities with specific subcategories consisting of product-specific and country-specific markets. The type I error of the entire portfolio of export opportunities is equal to $4.5 \%$ when compared to the initial reference group of good export opportunities. Since the model is highly dependent on historical data, it favours the opportunities in traditional industries and disadvantages new dynamic sectors, which implies that the model is not very stable in the dynamic environment of international trade and thus requires recalibration in the future. Further research should also aim at developing a more robust index to account for import restric-

$580.8 \%$ of Czech exports were exports to EU27 countries in 2012. 
tions and a more convenient parameter than distance between markets that takes into account the quality of infrastructure and is a better estimator of the costs of transport.

\section{Conclusion}

Our model for prioritising export opportunities is a helpful tool for optimising export activities and competitiveness of the Czech export policy. It identifies suitable export opportunities based on growth potential, absorption capacity and compatibility in relation to the Czech economy. It comes with substantial improvements compared to previous export models such as Cuyvers et al. (1995), Cuyvers (1996), Cuyvers (2004), Cuyvers et al. (2009) and Pearson et al. (2010), putting emphasis on the supply side of export opportunities, taking into account global value chains and enabling choice of the desired acceptable country risk and weights of indexes specific for the market and industry of interest. The model is thus more flexible and reflects the needs of individual sectors and countries compared to previous studies. The model is calibrated for the specific case of the Czech Republic, but may serve as guidance for building similar models for other countries.

\section{Appendix A}

Czech Export Strategy 2012-2020 defines 12 priority and 25 interest countries.

Priority countries: Brazil, China, India, Kazakhstan, Mexico, Russia, Serbia, Turkey, Ukraine, USA, Iraq, and Vietnam

Interest countries: Angola, Argentina, Australia, Azerbaijan, Belarus, Egypt, Ethiopia, Chile, Ghana, Croatia, Israel, Japan, South Africa, Canada, Colombia, Morocco, Moldova, Nigeria, Norway, Peru, Senegal, Singapore, United Arab Emirates, Switzerland, and Thailand

\section{References}

ANAND, R.; MISHRA, S.; LUNDSTROM, S. Sophistication in Service Exports and Economic Growth. World Bank-Economic Premise. 2011, no. 55, pp. 1-4.

BALASSA, B. Trade Liberalisation and "Revealed" Comparative Advantage. The Manchester School. 1965, vol. 33, no. 2, pp. 99-123.

CUYVERS, L.; DE PELSMACKER, P.; RAYP, G.; ROOZEN, I.T.M. A decision support model for the planning and assessment of export promotion activities by government export promotion institutions - the Belgian case. International Journal of Research in Marketing. 1995, vol. 12, no. 2, pp. 173-186.

CUYVERS, L. Export opportunities of Thailand: Export Decision support model approach. Journal of Euro-Asian management. 1996, vol. 12, no. 2, pp. 71-96.

CUYVERS, L. Identifying export opportunities: the case of Thailand. International Marketing Review. 2004, vol. 21 no. 3, pp. 255-278.

CUYVERS, L.; ROSSOUW, R.; STEENKAMP, E.; VIVIERS, W. Export Market Selection Methods and the Identification of Realistic Export Opportunities for South Africa Using a Export Decision Support Model [Working Paper Series 2009-03]. Trade \& Industrial Policy Strategies, 2009.

CzechTrade. 2013. BusinessInfo.cz. The Czech Trade Promotion Agency.

CZSO. 2012. Statistics and External Trade Database, Czech Statistical Office. 
FINGER, J.M.; KREININ, M.E. A Measure of Export Similarity and Its Possible Uses. The Economic Journal. 1979, vol. 89, no. 356, pp. 905-912.

HAVRLANT, D.; HUŠEK, R. Models of Factors Driving the Czech Export. Prague Economic Papers. 2011, vol. 3, pp. 195-215.

HIRSHMANN, A.O. The paternity of an index. American Economic Review. 1964, vol. 54, pp. 761.

IMF. 2006-2013. Data and Statistics. International Monetary Fund.

LAFAY, G. The Measurement of Revealed Comparative Advantages in MG Dagenais and P. A. Muet (eds.). International Trade Modelling, London: Chapman \& Hall, 1992.

OEC. 2008. Economic Complexity Index. The Observatory of Economic Complexity.

OECD. 2013. Country Risk Classification. Organization for Economic Co-operation and Development.

PEARSON, J.; VIVIERS, W.; CUYVERS, L. Identifying export opportunities: The case of South Africa. International Business Review. 2010, vol. 19, no. 4, pp. 345-359.

UN Comtrade. 2006-2010. Comtrade Database. United Nations Commodity Trade Statistics Database. World Bank. 2013. Ease of doing business indicator. World Bank. www.doingbusiness.org/rankings. WTO - OECD. 2013. Trade in Value Added, World Trade Organization and OECD joint initiative.

\title{
APPLICATION OF THE DECISION SUPPORT MODEL TO CZECH EXPORTS
}

\begin{abstract}
In this paper, we present our own modification of the Export Decision Support Model (EDSM) and its application on evaluation of export opportunities for Czech companies. The main objective of the model is to identify export opportunities which might help to target the export promotion policy of the Czech Republic. The EDSM methodology is based on sequential elimination of less interesting markets. We have amended and calibrated the EDSM for the Czech Republic and created a new variable - our Index of Export Opportunities - which classifies markets depending on their suitability for export. Calibration was performed on a data sample covering global trade data from 2006 to 2012. The results of the model have been used as a tool for an evidence-based export promotion policy in the Czech Republic. The results were tested by the real foreign demand for Czech products in specific industries and importing countries based on information from Czech embassies and trade promotion organisations.
\end{abstract}

Keywords: export, export decision support model, index of export opportunities, export strategy, simulation, calibration

JEL Classification: F13, F14 